OPEN ACCESS

Edited by:

Jiguo Qiu,

Nanjing Agricultural University, China

Reviewed by:

Chunyu Li,

Changzhou University, China

Mihai Leonte,

University of Rochester, United States

Hui Yun,

Lanzhou University, China

*Correspondence:

Mathilde J. Hedegaard mathed@hofor.dk mjhe@env.dtu.dk

Specialty section: This article was submitted to Toxicology, Pollution and the

Environment,

a section of the journal

Frontiers in Environmental Science

Received: 12 March 2020

Accepted: 19 May 2020

Published: 23 June 2020

Citation:

Hedegaard MJ,

Schliemann-Haug MA, Milanovic N,

Lee CO, Boe-Hansen $R$ and

Albrechtsen H-J (2020) Importance

of Methane Oxidation for Microbial

Degradation of the Herbicide

Bentazone in Drinking Water

Production. Front. Environ. Sci. 8:79.

doi: 10.3389/fenvs.2020.00079

\section{Importance of Methane Oxidation for Microbial Degradation of the Herbicide Bentazone in Drinking Water Production}

\author{
Mathilde J. Hedegaard ${ }^{1 *}$, Manuela A. Schliemann-Haug ${ }^{1}$, Nikola Milanovic', \\ Carson O. Lee ${ }^{1}$, Rasmus Boe-Hansen ${ }^{2}$ and Hans-Jørgen Albrechtsen ${ }^{1}$
}

${ }^{1}$ DTU Environment, Technical University of Denmark, Kongens Lyngby, Denmark, ${ }^{2}$ Krüger A/S, Søborg, Denmark

Bentazone is a herbicide, which is frequently detected in groundwater due to its mobility and persistence in aquifers. Groundwater is used as a drinking water source all over the world, and sustainable methods to remove pesticides at low concentrations are urgently needed since pesticide contaminations can adversely affect human health. The aim of this study was to investigate whether microbial bentazone degradation was associated with methane oxidation in full-scale drinking water treatment plants. To this end, we investigated bentazone biodegradation in microcosms with water and filter material from rapid sand filters, or biomass from aeration systems, and we investigated the statistical relation between the presence of methane and bentazone in groundwater abstraction wells. An array of evidence supported an association between bentazone degradation and methane oxidation in the biological treatment process. The biodegradation potential of bentazone was associated with the presence of methane in the raw water at 14 different water works. In contrast, no association was observed with any of the other investigated inorganic energy sources, e.g., ammonium. Addition of acetylene inhibited methane oxidation and the bentazone degradation in filter material from two investigated waterworks. Biomass from the aeration tanks degraded bentazone, but only while oxidizing methane. Bentazone removal rates and methane removal rates correlated significantly across all the experiments with biomass or filter material, with an overall transformation yield of $15 \pm 1 \times 10^{-5} \mathrm{~mole}_{\mathrm{BTZ}} / \mathrm{mole}_{\mathrm{CH} 4}$. This demonstrated that the bentazone degradation was conducted by the same type of process in all the investigated communities, governed by methane oxidation. Furthermore, based on more than 10.000 water analyses from waterworks abstraction wells in Denmark, bentazone was detected significantly less frequent in wells with high methane concentrations (>1 mg/L) than in wells without methane. This suggests that biological treatment of bentazone contamination in drinking water may be achieved using methanotrophs.

Keywords: co-metabolic biodegradation, methane oxidation, pesticides, bentazone, rapid sand filters, drinking water treatment, groundwater 


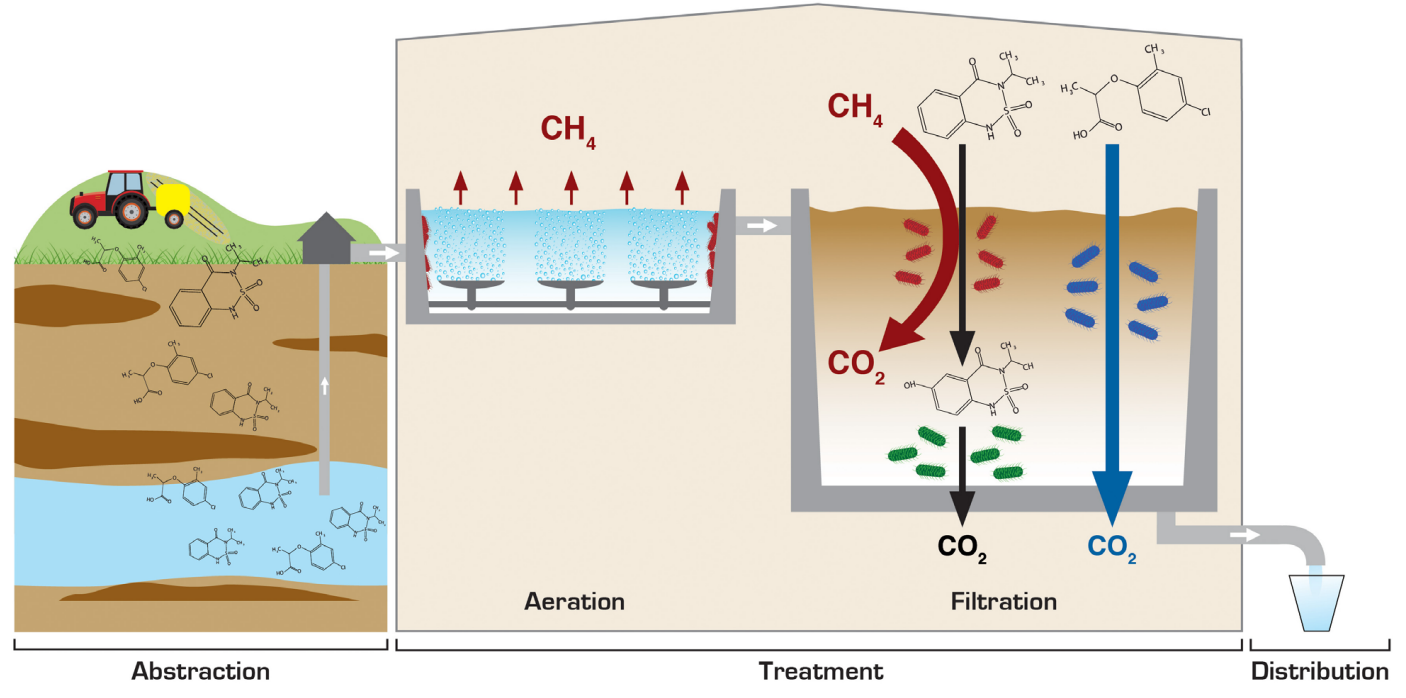

GRAPHICAL ABSTRACT | Conceptual drawing of microbial pesticide degradation processes in drinking water production

\section{INTRODUCTION}

Groundwater constitutes a major drinking water source worldwide (IWA, 2014). Unfortunately, pesticides are frequently detected in groundwater, especially those which have been extensively used, are highly mobile and persistent (Benner et al., 2013). In Denmark, traces of pesticides were detected in $40.8 \%$ of the groundwater abstraction wells (2018) (GEUS and Danish Ministry of Climate Energy and Utilities, 2019). In the European Union (EU), the guideline value for pesticides and their degradation products is $0.1 \mu \mathrm{g} / \mathrm{L}$ for a single compound in drinking water, or $0.5 \mu \mathrm{g} / \mathrm{L}$ for the sum of all pesticides (European Commission, 1998). One of the most frequently detected pesticides in groundwater is the herbicide bentazone (Kolpin et al., 2000; Schipper et al., 2008; GEUS and Danish Ministry of Climate Energy and Utilities, 2019), and bentazone was found in $31.7 \%$ of 164 groundwater samples in EU, with the average concentration of $0.116 \mu \mathrm{g} / \mathrm{L}$ and maximum concentration of $10.55 \mu \mathrm{g} / \mathrm{L}$ (Loos et al., 2010).

Pesticides can be removed from drinking water by several processes such as activated carbon filtration, reverse osmosis or ozonation followed by biological activated carbon filtration (Camel and Bermond, 1998; van der Hoek et al., 1999). However, if pesticide contaminations can be managed through simple biological water treatment, with aeration of anaerobic groundwater followed by rapid sand filtration, it would be of large practical and commercial interest, since this treatment process is more environmentally sustainable (Godskesen et al., 2011).

Biological rapid sand filters are widely used to remove iron, manganese and ammonium in drinking water production (Mouchet, 1992; Lytle et al., 2007; Tekerlekopoulou et al., 2013; Lee et al., 2014) and may also remove and mineralize some organic trace contaminants, such as pharmaceuticals and pesticides (Zearley and Summers, 2012; Hedegaard and Albrechtsen, 2014; Vandermaesen et al., 2019). As an example, full-scale rapid sand filters at a groundwater-based waterworks removed the herbicide mecoprop (MCPP) to below detection limit (Hedegaard et al., 2014).

In many areas, groundwater contains methane. For instance, in Denmark the average methane concentration in groundwater is $0.67 \mathrm{mg} / \mathrm{L}$, with a maximum concentration of $61 \mathrm{mg} / \mathrm{L}$ (Maksimavičius and Roslev, 2020), while in United States the average is $0.44 \mathrm{mg} / \mathrm{L}$, and the concentration can be as high as $150 \mathrm{mg} / \mathrm{L}$ (Kulongoski and McMahon, 2019). Methane in the raw water might sustain growth of methanotrophs in the rapid sand filters, and so, methanotrophs are frequently found in biological rapid sand filters along with e.g., ammonium oxidizing bacteria (Albers et al., 2015; Gülay et al., 2016; Palomo et al., 2016; Maksimavičius and Roslev, 2020). Both methanotrophs and ammonium oxidizing bacteria are known to perform co-metabolic degradation (e.g., Colby et al., 1977; Forrez et al., 2009; Semrau et al., 2010; Xu et al., 2017), of some organic trace contaminants, which are degraded along with the primary substrate (e.g., methane, ammonium or organic compounds) (Dalton and Stirling, 1982; Alexander, 1994). This process has gained attention, since it allows degradation of trace contaminants even at concentrations that would not sustain specific degraders ( $\mu \mathrm{g} / \mathrm{L})$ (e.g., Semprini et al., 1990; Semrau et al., 2010). Taking advantage of these co-metabolic properties of certain bacteria may pose a possible strategy for removing some organic trace contaminants using biological rapid sand filters (Benner et al., 2013; Papadopoulou et al., 2019).

Our previous work has shown how a methanotrophic enrichment culture co-metabolically transformed bentazone to 6-OH-, 8-OH-, isopropyl-OH-, and di-OH-bentazone which accumulated in this enrichment culture (Hedegaard et al., 2018). However, these hydroxylated transformation products could not be detected during bentazone degradation in filter material from a waterworks, whereas the presence of further degraded transformation products demonstrated the importance 
of other metabolic pathways in these systems (Hedegaard et al., 2019). Thus, it is still unknown whether the initial bentazone degradation step in filter material depends on methane oxidation or other biological processes and to what extent this is valid in water treatment system. In order to take advantage of bentazone degradation, it is essential to know to which extent this process depends on methane oxidation in water treatment.

The aim of this study was to investigate if bentazone degradation was associated with methane oxidation in biological drinking water treatment. To achieve this, we investigated:

- To which extent the bentazone biodegradation potential in filter material from 14 different waterworks was associated with the presence of any of the different inorganic energy sources for autotrophic microorganisms in the raw water.

- Whether inhibition of monooxygenases affected bentazone degradation in filter material and whether active methane oxidation was essential for bentazone degradation in biomass from the waterworks aeration system.

- Whether bentazone removal rates were associated with methane removal rates in biological material collected from waterworks.

- Whether methanotrophs could contribute to bentazone degradation in full-scale environmental systems, thus, whether presence of bentazone was associated with absence of methane in groundwater abstraction wells.

Experiments were conducted in microcosms with material and water from full-scale waterworks.

\section{MATERIALS AND METHODS}

\section{Chemicals}

Mineralization and removal at low concentrations $(1 \mu \mathrm{g} / \mathrm{L})$ was investigated using [carbonyl- ${ }^{14} \mathrm{C}$ ]-bentazone (Izotop, Institute of Isotopes Co., Ltd., Hungary). The radiochemical purity of [carbonyl- ${ }^{14} \mathrm{C}$ ]-bentazone was $100 \%$ (chemical purity $99.77 \%$ ) according to the manufacturer. Stock solutions were prepared in sterile MilliQ water, and the concentration was validated by HPLC-DAD immediately before the experiment. Bentazone (chemical purity 99.1\%, Dr. Ehrenstorfer $\mathrm{GmbH}$ ) was dissolved in sterile MilliQ water at least 1 day prior to the experiment. Acetylene was added from a gas flask (see Supplementary Information).

\section{Waterworks}

Across Denmark we selected 14 groundwater-based waterworks which represented different raw water quality (Table 1). At all the selected waterworks the water treatment included aeration, and filtration in primary and secondary rapid sand filters. In most waterworks, the water was aerated by stair aerators, but in some plants aeration tanks or intensive tray aerators (INKA chambers) were used to assure sufficient stripping of methane and/or hydrogen sulfide. Filter material was collected from the prefilter's top layer $(10 \mathrm{~cm})$ by an aluminum bucket on an extendable shaft, disinfected with $1 \%$ hypochloride. At two waterworks receiving methane-rich raw water, biomass samples were collected by scraping the sides of the aeration tanks with the aluminum bucket. Water was collected from the inlet to the clean water tanks.

\section{Microcosms and Sampling}

Bentazone degradation was investigated in batch experiments (for specific conditions in each experiment, e.g., number of replicates, controls, methane, acetylene, and bentazone concentrations, see Table 2). Either $100 \mathrm{~g}$ filter material or $5 \mathrm{~mL}$ biomass from aeration tanks was collected and transferred to $300 \mathrm{~mL}$ serum bottles along with $100 \mathrm{~mL}$ water within 2 days. The serum bottles had been acid-washed and heated to $555^{\circ} \mathrm{C}$ for $12 \mathrm{~h}$. Controls with filter material were autoclaved three times $\left(20 \mathrm{~min}, 1 \mathrm{bar}\right.$ and $121^{\circ} \mathrm{C}$, the microcosms cooled for approx. $30 \mathrm{~min}$ inside the autoclave - to less than $80^{\circ} \mathrm{C}$ - before autoclaving was repeated). The serum bottles were sealed with autoclaved Teflon coated rubber stoppers and aluminum lids. In microcosms with methane present, $31 \mathrm{~mL}$ of the headspace was replaced by methane using a syringe with a needle through the rubber stopper. To mimic waterworks conditions microcosms were incubated in the dark at $10^{\circ} \mathrm{C}$ and placed on a shaker table (100-20 rpm). We have previously shown that methane oxidation was successfully inhibited by acetylene in a methanotrophic enrichment culture (Hedegaard et al., 2018). Therefore, in inhibited controls we added acetylene to a concentration of $26 \mathrm{mg} / \mathrm{L}$ in the water phase by replacing $8 \mathrm{~mL}$ of the headspace with acetylene using a syringe with a needle through the rubber stopper (Table 2).

Bentazone was added to the microcosms at time zero using a syringe with a needle through the rubber stopper. During the experiment water samples were collected by a syringe with a needle through the rubber stopper. All the collected water samples were replaced by an equivalent volume of sterile air. The collected water samples were filtered through a $0.22 \mu \mathrm{m}$ nylon GF filter (Frisenette Aps, Q- $\max ^{\circledR}$ GPF Syringe Filters,

TABLE 1 | Concentration of water quality parameters for investigated waterworks.

\begin{tabular}{lccccc}
\hline WW & $\begin{array}{c}\mathbf{N H}_{\mathbf{4}}{ }^{+} \\
(\mathbf{m g - N} / \mathbf{L})\end{array}$ & $\begin{array}{c}\mathbf{F e} \\
(\mathbf{m g} / \mathbf{L})\end{array}$ & $\begin{array}{c}\mathbf{M n} \\
(\mathbf{m g} / \mathbf{L})\end{array}$ & $\begin{array}{c}\mathbf{C u} \\
(\boldsymbol{\mu} \mathbf{g} / \mathbf{L})\end{array}$ & $\begin{array}{c}\mathbf{C H}_{\mathbf{4}} \\
(\mathbf{m g} \mathbf{L})\end{array}$ \\
\hline Brandsbjerg & $1.3-4.2$ & $0.5-1.7$ & $0.3-0.7$ & - & 1.4 \\
Bregnerød & 0.2 & 2.5 & 0.28 & - & 0.068 \\
Brønderslev & $0.06-0.88$ & $0.16-0.44$ & $0.08-0.3$ & - & 0.11 \\
Føllenslev & 0.53 & $3.5-4.0$ & 0.21 & - & 0.14 \\
Gilleleje & 0.49 & 0.73 & 0.05 & $<0.2$ & 10.6 \\
Hareskov & 0.63 & 5.8 & 0.19 & - & 0.04 \\
Herning & $0.14-0.21$ & $0.95-5.5$ & $0.15-0.26$ & - & 0.088 \\
Kerteminde & $0.01-0.07$ & $0.013-0.1$ & $0.002-0.008$ & - & $<0.01$ \\
Lønstrup & $0.02-0.05$ & $0.04-0.06$ & $0.01-0.6$ & - & $<0.01$ \\
Sjaelsø Plant I & 0.35 & 2.29 & 0.09 & $<0.2$ & 0.24 \\
Sjaelsø Plant II & $0.92-1.26$ & $0.38-2.6$ & $0.012-0.054$ & - & 17.9 \\
Stenholt & $>1.0$ & 0.04 & 0.005 & $<0.2$ & 20.6 \\
Strib & $0.02-0.1$ & $0.002-0.09$ & $0.001-0.01$ & - & $<0.01$ \\
Ullerup & 0.87 & 0.12 & 0.004 & 1.96 & 14.9 \\
\hline
\end{tabular}

$\mathrm{CH}_{4}$ is the maximum methane concentration in the raw water. 
TABLE 2 | Experimental set-up.

\begin{tabular}{|c|c|c|c|c|c|c|}
\hline & Microcosms & Autoclaved controls & Inhibited controls & Methane added & 14C-bentazone & $\begin{array}{c}\text { Bentazone } \\
\text { (HPLC) }\end{array}$ \\
\hline & (number) & (number) & $\begin{array}{c}\text { (number, } \\
\text { concentration) }\end{array}$ & $\begin{array}{c}\text { (number, } \\
\text { concentration) }\end{array}$ & $\begin{array}{c}\text { (number, } \\
\text { concentration) }\end{array}$ & $\begin{array}{c}\text { (number, } \\
\text { concentration) }\end{array}$ \\
\hline \multicolumn{7}{|c|}{ Screening of bentazone degradation potential at 14 different waterworks } \\
\hline Brandsbjerg & 2 & 1 & - & - & $3(0.5-1 \mu \mathrm{g} / \mathrm{L})$ & - \\
\hline Bregnerød & 2 & 1 & - & - & $3(0.5-1 \mu \mathrm{g} / \mathrm{L})$ & - \\
\hline Brønderslev & 2 & 1 & - & - & $3(0.5-1 \mu \mathrm{g} / \mathrm{L})$ & - \\
\hline Føllenslev & 2 & 1 & - & - & $3(0.5-1 \mu \mathrm{g} / \mathrm{L})$ & - \\
\hline Gilleleje & 4 & 1 & - & - & $4(0.5-1 \mu \mathrm{g} / \mathrm{L})$ & 1 (1 mg/L) \\
\hline Hareskov & 2 & 1 & - & - & $3(0.5-1 \mu \mathrm{g} / \mathrm{L})$ & - \\
\hline Herning & 2 & 1 & - & - & $3(0.5-1 \mu \mathrm{g} / \mathrm{L})$ & - \\
\hline Kerteminde & 2 & 1 & - & - & $3(0.5-1 \mu \mathrm{g} / \mathrm{L})$ & - \\
\hline Lønstrup & 2 & 1 & - & - & $3(0.5-1 \mu \mathrm{g} / \mathrm{L})$ & - \\
\hline Sjaelsø Plant I & 4 & 1 & - & - & $4(0.5-1 \mu \mathrm{g} / \mathrm{L})$ & 1 (1 mg/L) \\
\hline Sjaelsø Plant II & 4 & 1 & - & - & $4(0.5-1 \mu \mathrm{g} / \mathrm{L})$ & 1 (1 mg/L) \\
\hline Stenholt & 4 & 1 & - & - & $4(0.5-1 \mu \mathrm{g} / \mathrm{L})$ & 1 (1 mg/L) \\
\hline Strib & 2 & 1 & - & - & $3(0.5-1 \mu \mathrm{g} / \mathrm{L})$ & - \\
\hline Ullerup & 4 & 1 & - & - & $3(0.5-1 \mu \mathrm{g} / \mathrm{L})$ & 1 (1 mg/L) \\
\hline \multicolumn{7}{|c|}{ Activity of monooxygenases } \\
\hline Sjaelsø Plant II & 2 & - & 2 (26 mg/L) & 4 (5 mg/L) & - & 4 (1 mg/L) \\
\hline Stenholt & 2 & - & 2 (26 mg/L) & 4 (5 mg/L) & - & 4 (1 mg/L) \\
\hline \multicolumn{7}{|c|}{ Biomass from aeration tanks } \\
\hline Ullerup & 3 & - & - & $3(5 \mathrm{mg} / \mathrm{L})^{*}$ & $3(0.5-1 \mu \mathrm{g} / \mathrm{L})$ & 2 (1 mg/L) \\
\hline Stenholt & 3 & - & - & $3(5 \mathrm{mg} / \mathrm{L})^{*}$ & $3(0.5-1 \mu \mathrm{g} / \mathrm{L})$ & $2(1 \mathrm{mg} / \mathrm{L})$ \\
\hline
\end{tabular}

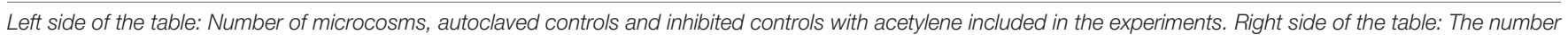
of the included microcosms to which methane, ${ }^{14} \mathrm{C}$-bentazone and/or bentazone was added and calculated initial concentration. ${ }^{*}$ Methane added after 21 days.

diameter $25 \mathrm{~mm}$ ). At the beginning of the experiments the oxygen concentration was $>10 \mathrm{mg} / \mathrm{L}$, and when concentrations decreased to below $5 \mathrm{mg} / \mathrm{L}$ during the experiments, pure oxygen was added. $\mathrm{pH}$ remained at 7.5-8 during the experiments.

\section{Analytical Approaches Methane, Oxygen, ${ }^{14} \mathrm{C}$-Bentazone and HPLC-DAD Measurements}

All below mentioned methods are described in details in Hedegaard et al. (2018). Methane concentration was measured every 1-3 days in all microcosm with methane, and based on these measurements the methane consumption was calculated. A sample of $50 \mu \mathrm{L}$ was collected from the headspace of the microcosms and analyzed for methane by GC-FID. Aqueous oxygen saturation was monitored by Oxygen-Sensitive Minisensors and a fiber optic oxygen meter (Fibox 3, Loligo Systems ApS). The concentration of ${ }^{14} \mathrm{C}$-bentazone in the water phase and the ${ }^{14} \mathrm{CO}_{2}$ produced from mineralization was quantified by a double vial system (Janniche et al., 2010). Water samples for bentazone analysis by HPLC-DAD were preserved with acetic acid and analyzed within few days.

\section{Data From Groundwater Abstraction Wells}

Data were collected from the public Danish "Jupiter database" which contains all historical data from drinking water wells (accessed at the 2nd to the 5th of December 2016) (GEUS and Danish Ministry of Energy Utilities and Climate, 2016). We included data from waterworks wells where water samples for methane and bentazone-analysis were collected at the same time, and the data was divided into four groups depending on the presence/absence of methane and presence/absence of bentazone. A well was considered as "Containing methane" if at least one sample showed a methane concentration higher than $1 \mathrm{mg} / \mathrm{L}$ and/or "Containing bentazone" if the concentration of bentazone in a least one sample was above the detection limit $(0.01 \mu \mathrm{g} / \mathrm{L})$.

\section{Statistics}

The data were treated with the statistical software GraphPad Prism 6, performing: Correlation tests (Spearman), linear regression models, including tests for whether slopes and intercepts were significantly different (equivalent to ANCOVA), and Fisher's exact test.

\section{RESULTS AND DISCUSSION}

\section{Methane in the Raw Water and Removal of Bentazone in Filter Material}

Fourteen waterworks with various raw water methane concentrations ranging from below detection limit $(<0.01 \mathrm{mg} / \mathrm{L})$ to $21 \mathrm{mg} / \mathrm{L}$ were screened for a bentazone degradation potential 


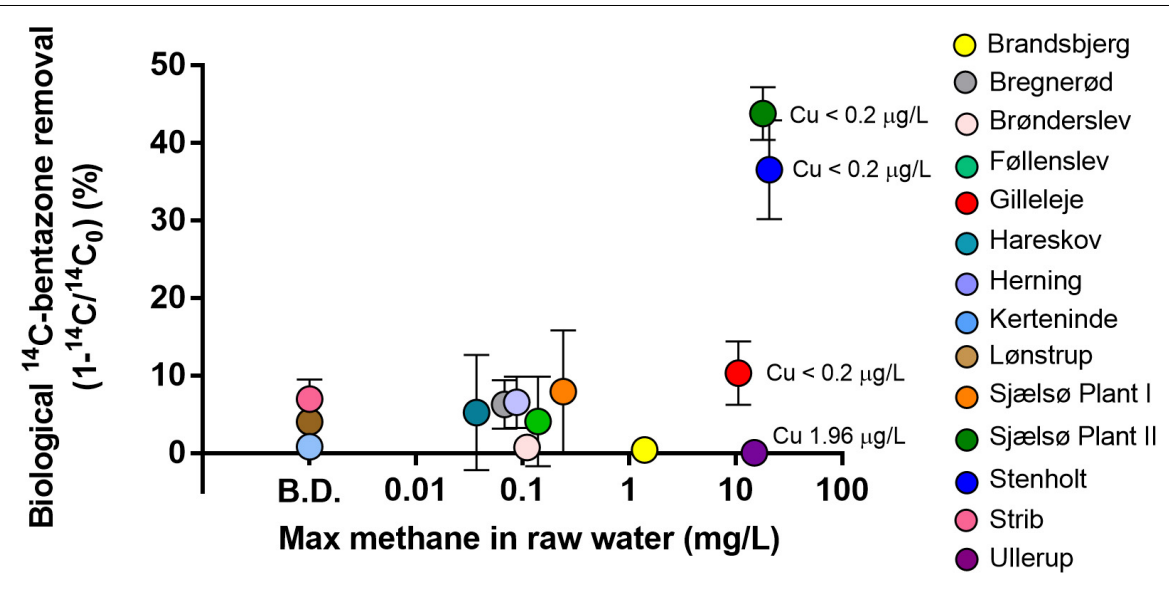

FIGURE 1 | Biological removal of ${ }^{14} \mathrm{C}$-bentazone $(1 \mu \mathrm{g} / \mathrm{L})$ in 14 different waterworks. Removal was measured in active microcosms (duplicates or triplicates) and autoclaved controls (single microcosm) after 5-7 days. The biological removal is the removal in the active microcosms minus the removal in the control (Hedegaard, 2018).

and its relation to raw water chemistry. The removal of bentazone was studied in microcosms mimicking the conditions in the sand filters (initial concentration at approx. $1 \mu \mathrm{g} / \mathrm{L}$ ), and the difference in removal of ${ }^{14} \mathrm{C}$-bentazone in autoclaved controls and biologically active microcosms expressed the biological removal potential in the different filter materials. In all 10 waterworks with less than $2 \mathrm{mg}$ methane/L in the raw water the biological removal of bentazone was low $(<8 \%)$ during 5-7 days of monitoring. The biological removal of bentazone did not lead to mineralization (no ${ }^{14} \mathrm{CO}_{2}$ was detected during the experiments) at any of these waterworks (Figure 1). At Ullerup waterworks the ${ }^{14} \mathrm{C}$-bentazone removal was insignificant and at Gilleleje waterworks it was low (10\%) although methane was present (15 and $11 \mathrm{mg}$ methane/L, respectively). However, at the two waterworks, with the highest methane concentrations (17-21 mg/L) (Sjaelsø Plant II and Stenholt), bentazone removal was substantially higher $(37-44 \%)$ than at all other waterworks (Figure 1).

Rapid sand filters represent a complex microbial environment (Albers et al., 2015; Gülay et al., 2016), where several abiotic and biological processes occur simultaneously. Besides methanotrophs, other groups of bacteria in these filters have co-metabolic properties, e.g., both ammonium and manganese oxidizing bacteria are associated with degradation of trace organic contaminants (Forrez et al., 2009). The raw water chemistry is governing the composition of the microbial community in the rapid sand filters (Albers et al., 2015; Gülay et al., 2016), and the presence of methane in the raw water allows the presence of methanotrophs in the filter sand (Maksimavičius and Roslev, 2020). Therefore, we investigated for relations between the presence of inorganic energy sources for autotrophic microorganisms in the raw water (methane, ammonium, iron, and manganese) and the bentazone degradation potential. We divided the waterworks into four groups based on the presence of a compound in the raw water (for methane, ammonium and iron the limit was set to $>1 \mathrm{mg} / \mathrm{L}$, for manganese $>0.1 \mathrm{mg} / \mathrm{L}$ ) and whether the filter sand showed a substantial bentazone degradation potential (>10\%). All nine waterworks with low methane concentrations $(<1 \mathrm{mg} / \mathrm{L})$ also showed low bentazone degradation potential $(<10 \%)$. Two waterworks had high methane concentrations $(>1 \mathrm{mg} / \mathrm{L})$ but did not show substantial bentazone degradation $(<10 \%)$, while three waterworks with high methane concentrations $(>1 \mathrm{mg} / \mathrm{L})$ showed substantial bentazone degradation $(>10 \%)$. The association between presence of methane in the raw water and the potential for biological degradation of bentazone in the filter sand was significant (Fisher's exact test, $P=0.0275$ ). In contrast, we observed no association between bentazone degradation potential and presence of other inorganic energy sources such as ammonium, iron or manganese.

Filter material from most waterworks removed microbiologically a fraction of bentazone (up to $8 \%$ ), independent of the methane concentration in the raw water. So a minor fraction of the bentazone degradation was not associated with methane oxidation (Figure 1).

The dynamics of the bentazone removal in filter material from five of the waterworks (Sjaelsø Plant I and II, Gilleleje, Ullerup and Stenholt) was studied at both high concentrations ( $1 \mathrm{mg} / \mathrm{L}$ bentazone measured by HPLC-DAD), and low concentrations $\left(1 \mu \mathrm{g} / \mathrm{L}\right.$, investigated as ${ }^{14} \mathrm{C}$-activity) for 14 days. In both approaches, bentazone removal in the filter material from Sjaelsø Plant II and Stenholt was much larger than in filter material from the remaining waterworks (Supplementary Figure S1). However, even though degradation clearly followed a linear trend through the entire period when measured by HPLC (Supplementary Figure S1A), the dissolved ${ }^{14} \mathrm{C}$-activity did not decrease substantially after 1 day at Sjaelsø Plant II, or after 7 days at Stenholt waterworks (Supplementary Figure S1B), probably due to formation of transformation products (Hedegaard et al., 2019).

In spite of the substantial bentazone removal in filter material from Stenholt, degradation did not lead to ${ }^{14} \mathrm{CO}_{2}-$ production, in contrast to the filter material from Sjaelsø Plant II (Supplementary Figure S1C). Hence, the microbial 
community in the filter material from Stenholt only conducted the initial transformation of bentazone, while it was unable to mineralize the metabolites completely. In contrast, some of the initial bentazone was completely mineralized in filter material from Sjaelsø Plant II (Supplementary Figures S1A,C; Hedegaard et al., 2019).

\section{Inhibition of Methane Oxidation and the Effect on Bentazone Removal in Filter Material}

Acetylene inhibits methane monooxygenases (MMO), as well as ammonium monooxygenases (AMO) (Prior and Dalton, 1985; Sullivan and Chase, 1996). To investigate whether the degradation of bentazone in filter material was conducted by monooxygenases, acetylene was added to microcosms with filter material from the two waterworks with the largest bentazone degradation potential (Sjaelsø Plant II and Stenholt). Before addition of acetylene, the microcosms from each waterworks all consumed methane at an equal rate (Figures 2A,B). Acetylene efficiently inhibited methane consumption immediately when added to the microcosms (at time: -2 days), while microcosms without acetylene addition continued to consume methane (Figures 2A,B), and thus microcosms with acetylene worked as a control without methane oxidation. Bentazone was added to all microcosms (at time 0 days), and in microcosms from both waterworks significantly less bentazone was removed in presence of acetylene than without (Sjaelsø Plant II: $P=0.00043$; Stenholt: $P<0.0001$ ) (Figures 2C,D and Table 3). Thus, the major fraction of bentazone removal in filter material was caused by the activity of monooxygenase.

However, a minor fraction of bentazone was removed in the presence of acetylene inhibiting monooxygenases, which suggests
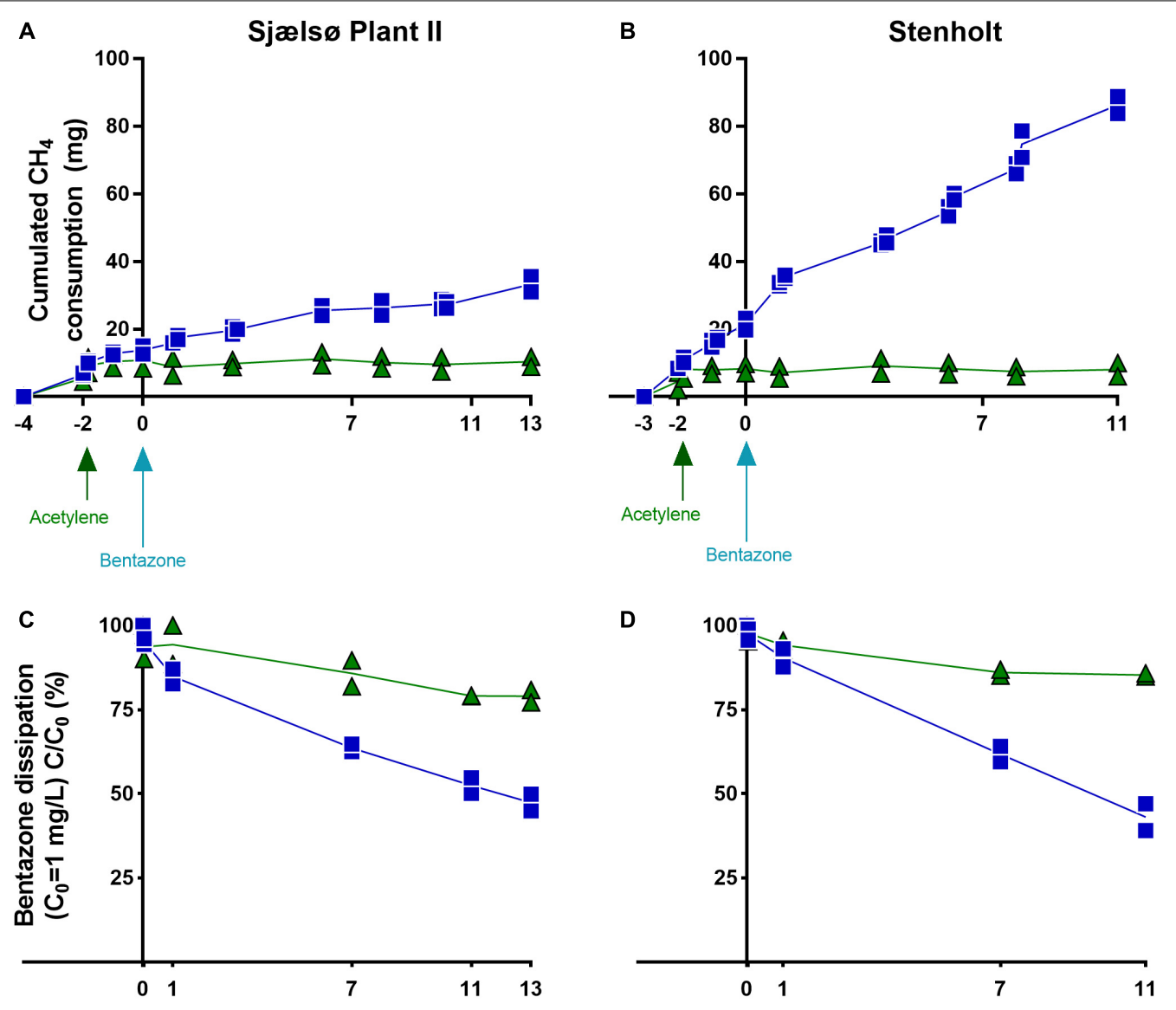

Time since bentazone addition (days)

Time since bentazone addition (days)

$-\square-$ Bentazone + methane
$\triangle$ Bentazone + methane + acetylene

FIGURE 2 | Methane oxidation and bentazone removal and the effect of acetylene. Methane oxidation and bentazone removal (1 mg/L) in filter sand from Sjaelsø Plant II and Stenholt in active microcosms and microcosms with acetylene (26 mg/L) (all in duplicates). (A) Methane consumption in filter sand from Sjaelsø Plant II. (B) Methane consumption in filter sand from Stenholt. (C) Bentazone removal in filter sand from Sjaelsø Plant II. (D) Bentazone removal in filter sand from Stenholt (Hedegaard, 2018). 

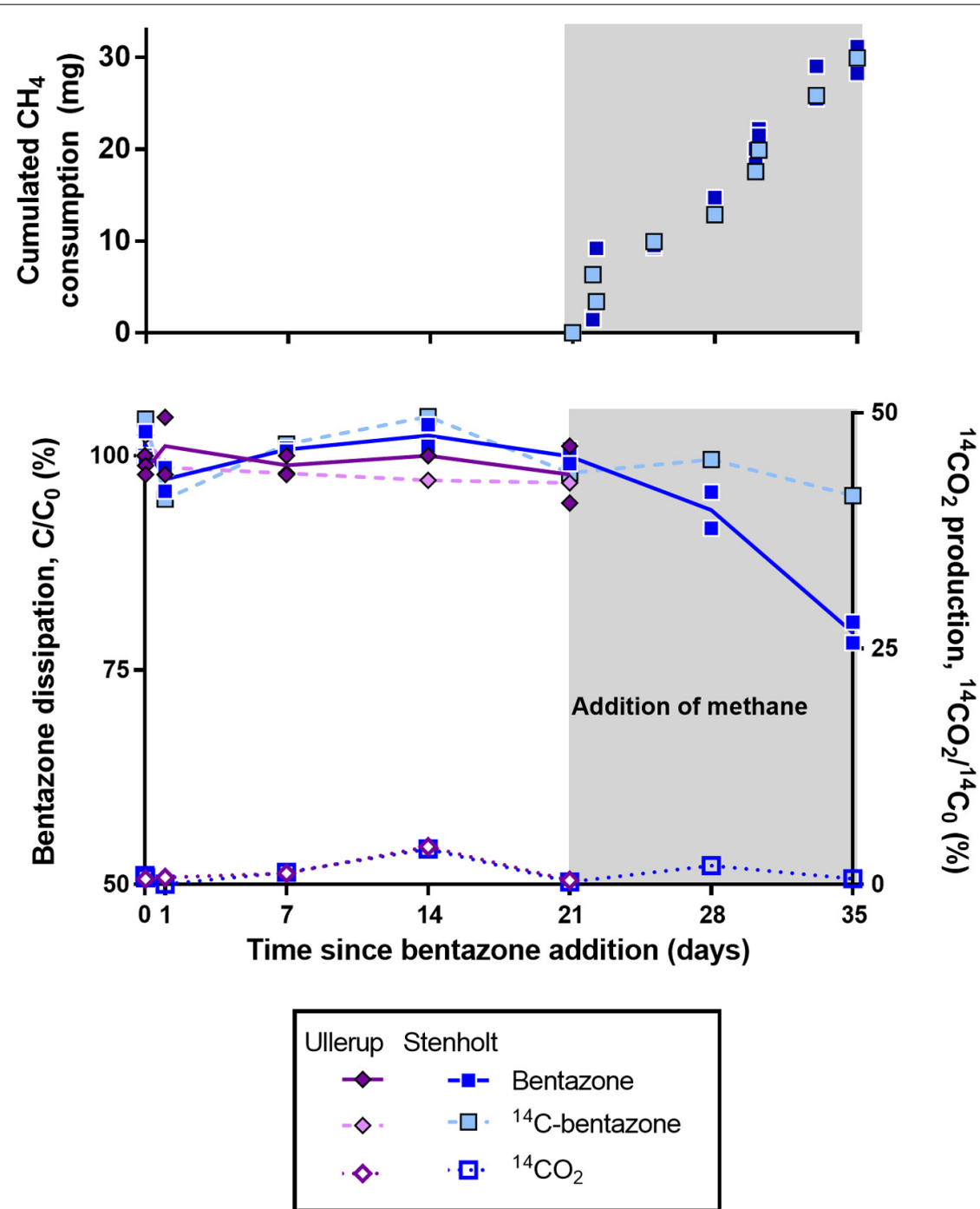

FIGURE 3 | Bentazone removal by methanotrophic biomass from aeration tanks. Microcosms with $5 \mathrm{~mL}$ biomass from sides of aeration tanks at Ullerup and Stenholt waterworks, $100 \mathrm{~mL}$ effluent water and bentazone (1 mg/L, duplicates) or ${ }^{14} \mathrm{C}$-carbonyl-bentazone (1 $\mu \mathrm{g} / \mathrm{L}$, single microcosm). Top: the cumulated consumption of methane in microcosms from Stenholt. Bottom: the removal of bentazone in the microcosms (Hedegaard, 2018).

other degradation pathways not associated with monooxygenases to contribute to the bentazone removal in filter material.

\section{Bentazone Removal by Methanotrophic Biomass From Aeration Tanks}

In aeration systems, some methane is stripped off, or biologically oxidized. Consequently, the methane concentrations are higher in the aeration systems than in the following rapid sand filters (Maksimavičius and Roslev, 2020). Therefore, we investigated if biomass scraped from the surfaces of the aeration systems could degrade bentazone, and whether this removal was associated with methane oxidation.

In absence of methane, biomass from the aeration tanks at Ullerup and Stenholt waterworks did not degrade bentazone within an incubation period of 21 days (Figure 3). After this period the experiment with biomass from Ullerup was stopped, while we added methane to microcosms with biomass from Stenholt waterworks. Methane consumption started immediately when methane was added to the microcosms (Figure 3 top), and the bentazone removal started simultaneously - the biomass removed $21 \%$ of the bentazone (initial concentration $1 \mathrm{mg} / \mathrm{L}$ ) within the next 14 days (Figure 3). Subsequently, bentazone transformation only occurred during active methane oxidation. The biomass neither removed ${ }^{14} \mathrm{C}$-activity from the water phase nor produced ${ }^{14} \mathrm{CO}_{2}$, so the biomass apparently transformed bentazone into transformation products accumulating in the water phase. A similar transformation was observed with a methanotrophic enrichment from a rapid sand filter (Hedegaard et al., 2018). Bentazone transformation by biomass from the aeration tanks at Stenholt thus clearly depended on methane oxidation. 


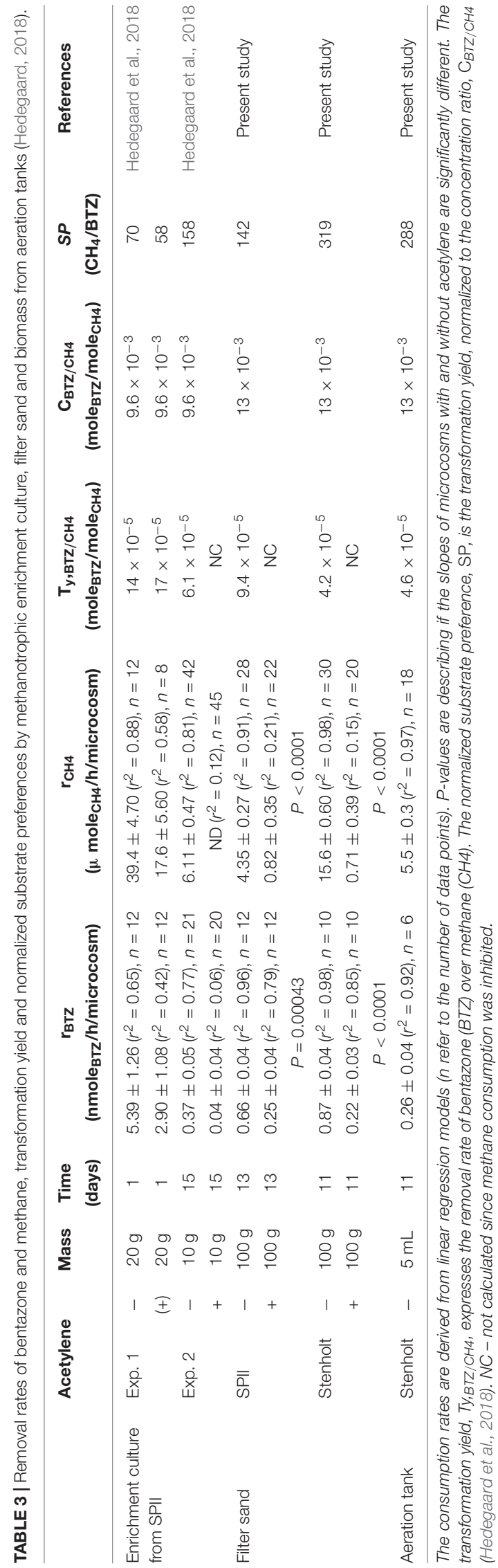

\section{Transformation Yield of Bentazone as a Function of Methane Oxidation}

Transformation yields express moles of degraded trace contaminant per mole of methane consumed (Anderson and Mccarty, 1997). With data from all experiments in our present and previous studies, including filter material from two different waterworks, biomass from an aeration tank and a methanotrophic enrichment culture (Hedegaard et al., 2018), we investigated for an association between bentazone degradation rate and rate of methane removal (estimated by linear regression models, data in Table 3) across all the experiments. The bentazone removal rate correlated significantly with the methane removal rate across the six experiments $(P=0.0583)$ (Figure 4$)$, resulting in an overall transformation yield, $T_{y, B T Z / C H 4}$, of $15 \pm 1 \times 10^{-5}$ mole $_{\mathrm{BTZ}} / \mathrm{mole}_{\mathrm{CH} 4}$ (Table 3). Hence, all the investigated methanotrophic microbial communities transformed similar amounts of bentazone molecules per oxidized methane molecules, and this process did not depend on the origin of microbial community, such as where in the treatment process it was collected. The minor variation (up to a factor of four) in transformation yields (Table 3), could be due to differences in the composition of methanotrophic community, e.g., the number of soluble methane monooxygenase (sMMO) versus particulate methane monooxygenase (pMMO) expressing methanotrophs (Semrau et al., 2010; Jagadevan and Semrau, 2013). This indicated, that methane oxidation governed the bentazone removal in the different materials from waterworks.

To compare bentazone removal in water treatment systems with co-metabolic degradation of other trace contaminants conducted by MMO, the normalized substrate preferences were calculated [as suggested by Hedegaard et al. (2018)]. The normalized substrate preferences ranged from 142 to 319 in the present experiments, and was thus within the range reported for methanotrophic co-metabolic degradation of chlorinated ethenes (3-400) (Anderson and Mccarty, 1997; Hedegaard et al., 2018). A similar magnitude in the preference of MMO for methane over other trace contaminants, indicated that the bentazone removal in water treatment systems was similar to co-metabolic degradation of other trace contaminants conducted by MMO (Hedegaard et al., 2018).

\section{Association Between Methane and Bentazone in Groundwater Abstraction Wells}

When aerobic rain water infiltrates from the soil surface toward methane-rich aquifers, fronts will be produced in the subsurface between the downward infiltrating aerobic water and the deeper, anaerobic, methane containing groundwater, which creates growth conditions for methanotrophs (Amaral and Knowles, 1995; Kotelnikova, 2002). Laboratory investigations with aquifer material has shown the recalcitrance of bentazone in aquifers (Albrechtsen et al., 2001), also in methanogenic groundwater systems (Albrechtsen et al., 2001; Luo et al., 2019). However, when bentazone contaminated water infiltrates toward a methane-rich aquifer, we suggest that methanotrophs in the methane and oxygen counter gradients can degrade 
bentazone, which imply that presence of bentazone is less probable in anoxic methane-rich aquifers (Figure 5). To validate this assumption, we investigated whether bentazone was detected less frequently in methane-rich waterworks abstraction wells compared to wells without/small amounts of methane $(\leq 1 \mathrm{mg} / \mathrm{L})$. The groundwater methane concentration is high $(\geq 1 \mathrm{mg} / \mathrm{L})$ in $12 \%$ of the municipalities in Denmark (Maksimavičius and Roslev, 2020). Data from 15,437 wells showed that in 14,295 wells neither methane $(>1 \mathrm{mg} / \mathrm{L})$ nor bentazone was detected (Figure 5). 682 wells (4.4\%) contained substantial amounts of methane $(>1 \mathrm{mg} / \mathrm{L})$, but no bentazone $(<0.01 \mu \mathrm{g} / \mathrm{L})$, whereas bentazone was detected in 457 wells $(>0.01 \mu \mathrm{g} / \mathrm{L})$ without methane $(\leq 1 \mathrm{mg} / \mathrm{L})$. Only three wells showed simultaneous presence of methane and bentazone (Figure 5). Thus, a twosided Fischer's exact test demonstrated a significant correlation between the two parameters $(P<0.0001)$, and bentazone was detected significantly less frequently in wells with methane (>1 mg/L) (Figure 5). These results indicate that methanotrophs may protect the methane-rich groundwater against bentazone contaminations. Unfortunately, it is not possible from the data to clarify how geological settings may influence the absence of bentazone in methane-rich groundwater. For instance, methane-rich groundwater could be associated with confined aquifers, where there is a better protection against pesticide contamination.

\section{GENERAL DISCUSSION}

The majority of bentazone degradation in the filter material was inhibited by acetylene, which suggests that bentazone biotransformation in the filter material is connected with the

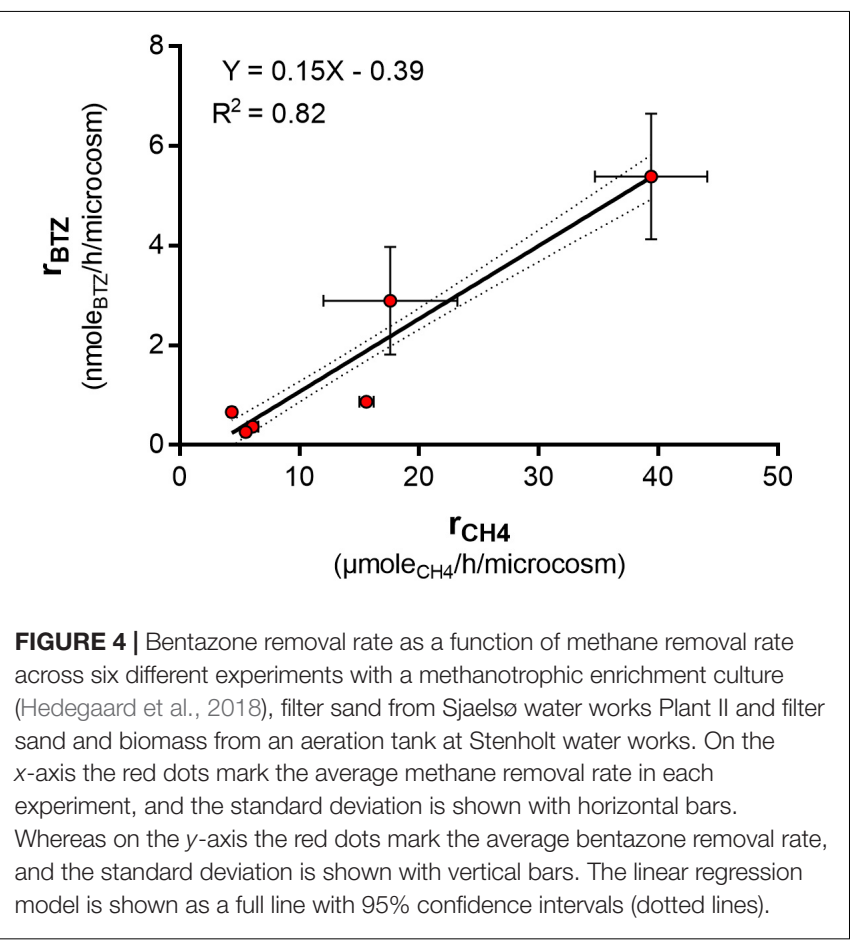

activity of monooxygenases. Unfortunately, it was not possible to distinguish between the activity of AMO and MMO (Bédard and Knowles, 1989; Lontoh et al., 2000) since both can be inhibited by acetylene and may be present in rapid sand filters (Albers et al., 2015; Gülay et al., 2016). However, the biological bentazone degradation potential in filter materials from 14 waterworks was associated with the presence of methane in the raw water, but neither with the presence of manganese, iron nor ammonium. Additionally, in the biomass from the waterworks aeration tanks the bentazone removal only occurred simultaneously with methane oxidation. Hence, several lines of evidence supported that the majority of bentazone transformation was associated with methane oxidation in biological water treatment processes.

Surprisingly, in one filter material (Ullerup) bentazone was not biologically removed (Figure 1 and Supplementary Figure S1), despite high concentrations of methane in the raw water. This may be explained by the high copper concentrations $(1.92 \mu \mathrm{g} / \mathrm{L})$ in the inlet to the filter, compared to the other waterworks $(<0.2 \mu \mathrm{g} / \mathrm{L})$ (Table 1). The copper concentration regulates the type of $\mathrm{MMO}$ being expressed: whether it is pMMO or sMMO (Semrau et al., 2010). sMMO is only expressed at low copper to biomass ratios (Semrau et al., 2013; Sirajuddin and Rosenzweig, 2015), and is the least specific of the two enzymes - capable of oxidizing aromatic compounds, while pMMO is limited to degrading alkanes of up to five carbon-atoms (Burrows et al., 1984; Trotsenko and Murrell, 2008; Semrau et al., 2010). Thus the 10 times higher copper concentrations at Ullerup waterworks than at the other waterworks could indicate a dominant formation of pMMO, which is suspected to be less efficient than sMMO to degrade bentazone.

Most waterworks had a minor potential for biological bentazone degradation, even in absence of methane in the raw water, however, this removal did not lead to mineralization of bentazone. Similarly, Vandermaesen et al. (2019) found that bentazone mineralization only rarely occurred in filter material in drinking water treatment plants. We also observed that some bentazone was removed in microcosms although methane oxidation was inhibited by acetylene. Thus, bentazone removal in filter material could not be ascribed to methanotrophic activity only. This conclusion is in agreement with our previous identification of a degradation pathway for bentazone in filter material. This degradation pathway is based on $\mathrm{N}$-methylation and is independent of methane oxidation (Hedegaard et al., 2019).

\section{CONCLUSION}

These investigations showed:

- The potential for biological bentazone removal was associated with the presence of methane in the raw water at 14 different water works, while it was not associated with the presence of other potential inorganic energy sources, ammonium, iron, and manganese. 


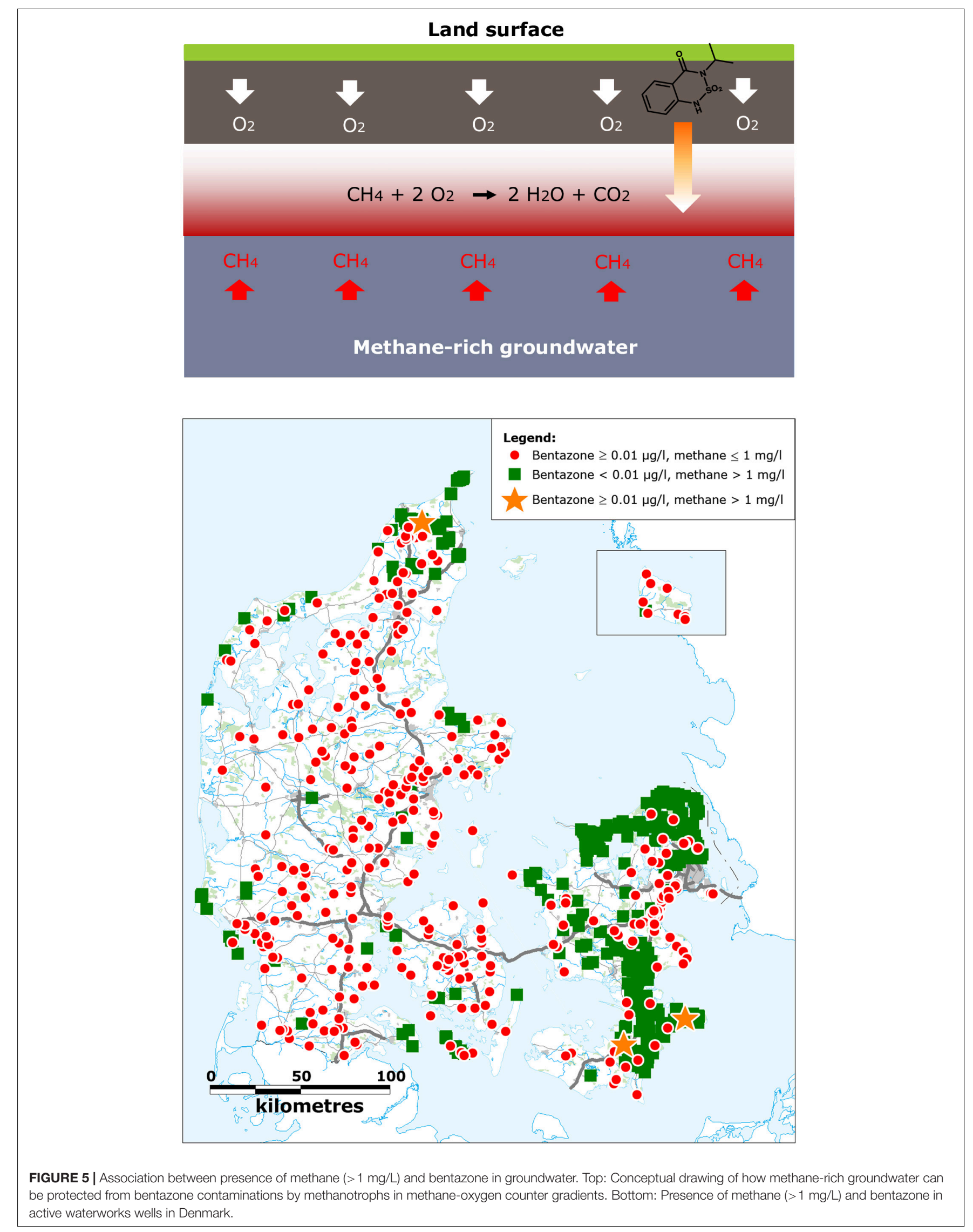


- Acetylene inhibited both the methane oxidation and the bentazone removal in filter material from two waterworks. Thus, the majority of bentazone degradation was related to monooxygenase activity.

- Biomass collected from the aeration tanks at a waterworks receiving methane-rich groundwater, degraded bentazone, but only while oxidizing methane.

- The ratio between bentazone removal rates and methane removal rates, were similar across different systems including enrichment cultures (other studies), filter material from different waterworks and biomass from aeration tanks, with the overall transformation yield of $15 \pm 1 \times 10^{-5}$ mole $_{\mathrm{BTZ}} /$ mole $_{\mathrm{CH} 4}$. Hence, all the investigated microbial communities transformed a similar amount of bentazone molecules per oxidized methane molecules.

- Bentazone was detected significantly less in groundwater abstraction wells with methane than in wells without methane $(P<0.0001)$, which indicated that methanotrophs living in methane and oxygen counter gradients, protected methane-rich groundwater from bentazone contaminations.

Thus, an array of evidence showed that bentazone degradation was connected to methane oxidation in drinking water treatment systems, indicating that MMO initiated the bentazone degradation. Therefore we suggest that bentazone degradation may be enhanced by stimulating the growth of methanotrophs in water treatment systems.

\section{DATA AVAILABILITY STATEMENT}

The datasets generated for this study are available on request to the corresponding author.

\section{REFERENCES}

Albers, C. N., Ellegaard-Jensen, L., Harder, C. B., Rosendahl, S., Knudsen, B. E., Ekelund, F., et al. (2015). Groundwater chemistry determines the prokaryotic community structure of waterworks sand filters. Environ. Sci. Technol. 49, 839-846. doi: 10.1021/es5046452

Albrechtsen, H. J., Mills, M. S., Aamand, J., and Bjerg, P. L. (2001). Degradation of herbicides in shallow Danish aquifers: an integrated laboratory and field study. Pest Manag. Sci. 57, 341-350. doi: 10.1002/ps.305

Alexander, M. (1994). Biodegradation and Bioremediation, 2nd Edn. Cambridge, MA: Academic Press.

Amaral, J. A., and Knowles, R. (1995). Growth of methanotrophs in methane and oxygen counter gradients. FEMS Microbiol. Lett. 126, 215-220. doi: 10.1016/ 0378-1097(95)00012-T

Anderson, J. E., and Mccarty, P. L. (1997). Transformation yields of chlorinated ethenes by a methanotrophic mixed culture expressing particulate methane monooxygenase. Appl. Environ. Microbiol. 63, 687-693.

Bédard, C., and Knowles, R. (1989). Physiology, biochemistry, and specific inhibitors of $\mathrm{CH} 4, \mathrm{NH} 4+$, and $\mathrm{CO}$ oxidation by methanotrophs and nitrifiers. Microbiol. Rev. 53, 68-84.

Benner, J., Helbling, D. E., Kohler, H.-P., Wittebol, J., Kaiser, E., Prasse, C., et al. (2013). Is biological treatment a viable alternative for micropollutant removal

\section{AUTHOR CONTRIBUTIONS}

$\mathrm{MH}, \mathrm{RB}-\mathrm{H}$, and H-JA had the idea for the study. $\mathrm{MH}$, MS-H, NM, CL, and H-JA designed the study. MH, MS$\mathrm{H}, \mathrm{NM}$, and $\mathrm{CL}$ carried out the experiments and analyzed the samples. Data from the Jupiter database was provided by RB-H. MS-H, NM, and CL did the initial data treatment of the experiments. $\mathrm{MH}$ did the analysis of data from Jupiter and overall data treatment, and wrote the manuscript. The major data interpretation was done by $\mathrm{MH}$ and $\mathrm{H}-\mathrm{JA}$, with contributions from MS-H, NM, RB-H, and CL. All authors commented on draft versions of the manuscript and provided feedback and ideas.

\section{FUNDING}

This research was partly financed by the Grundfos prize and the Trojan Horse - a new biotechnology for pesticide removal at drinking water sand filters (Innovation Fund Denmark, Grant No. 5157-00005B) and was a part of the Ph.D. thesis "Microbial degradation of pesticides in rapid sand filters used for drinking water treatment" by Hedegaard (2018).

\section{ACKNOWLEDGMENTS}

The authors thank the staff at the investigated waterworks for their help with filter material collection.

\section{SUPPLEMENTARY MATERIAL}

The Supplementary Material for this article can be found online at: https://www.frontiersin.org/articles/10.3389/fenvs. 2020.00079/full\#supplementary-material

in drinking water treatment processes? Water Res. 47, 5955-5976. doi: 10.1016/ j.watres.2013.07.015

Burrows, K. J., Cornish, A., Scott, D., and Higgins, I. J. (1984). Substrate specificities of the soluble and particulate methane mono-oxygenases of Methylosinus trichosporium OB3b. J. Gen. Microbiol. 130, 3327-3333. doi: 10.1099/00221287130-12-3327

Camel, V., and Bermond, A. (1998). The use of ozone and associated oxidation processes in drinking water treatment. Water Res. 32, 3208-3222. doi: 10.1016/ S0043-1354(98)00130-4

Colby, J., Stirling, D. I., and Dalton, H. (1977). The soluble methane monooxygenase of Methylococcus capsulatus (Bath). Its ability to oxygenate n-alkanes, $\mathrm{n}$-alkenes, ethers, and alicyclic, aromatic and heterocyclic compounds. Biochem. J. 165, 395-402. doi: 10.1042/bj1650395

Dalton, H., and Stirling, D. I. (1982). Co-metabolism. Philos. Trans. R. Soc. Lond. B Biol. Sci. 297, 481-496.

European Commission (1998). Council directive 98/83/EC of 3 november 1998 on the quality of water intended for human consumption. Off. J. Eur. Commun. L330, 32-54.

Forrez, I., Carballa, M., Noppe, H., De Brabander, H., Boon, N., and Verstraete, W. (2009). Influence of manganese and ammonium oxidation on the removal of 17 Alpha-Ethinylestradiol (EE2). Water Res. 43, 77-86. doi: 10.1016/j.watres.2008. 10.006 
GEUS and Danish Ministry of Climate Energy and Utilities (2019). Groundwater Monitoring 1989-2018. Available online at: https://www.geus.dk/media/22917/ grundvand1989-2018-rettet.pdf (accessed January 29, 2020).

GEUS and Danish Ministry of Energy Utilities and Climate (2016). Jupiter Database. GEUS \& Energi- Forsynings og Klimaministeriet. Available online at: http://www.geus.dk/DK/data-maps/jupiter/Sider/default.aspx

Godskesen, B., Zambrano, K. C., Trautner, A., Johansen, N.-B., Thiesson, L., Andersen, L., et al. (2011). Life cycle assessment of three water systems in Copenhagen-a management tool of the future. Water Sci. Technol. 63, 565-572. doi: 10.2166/wst.2011.258

Gülay, A., Musovic, S., Albrechtsen, H.-J., Al-Soud, W. A., Sørensen, S. J., and Smets, B. F. (2016). Ecological patterns, diversity and core taxa of microbial communities in groundwater-fed rapid gravity filters. ISME J. 10, 2209-2222. doi: 10.1038 /ismej.2016.16

Hedegaard, M. J. (2018). Microbial Degradation of Pesticides in Rapid Sand Filters Used for Drinking Water Treatment. Lyngby: DTU Environment, The Technical University of Denmark.

Hedegaard, M. J., and Albrechtsen, H. J. (2014). Microbial pesticide removal in rapid sand filters for drinking water treatment - potential and kinetics. Water Res. 48, 71-81. doi: 10.1016/j.watres.2013.09.024

Hedegaard, M. J., Arvin, E., Corfitzen, C. B., and Albrechtsen, H.-J. (2014). Mecoprop (MCPP) removal in full-scale rapid sand filters at a groundwaterbased waterworks. Sci. Total Environ. 499, 257-264. doi: 10.1016/j.scitotenv. 2014.08.052

Hedegaard, M. J., Deliniere, H., Prasse, C., Dechesne, A., Smets, B. F., and Albrechtsen, H.-J. (2018). Evidence of co-metabolic bentazone transformation by methanotrophic enrichment from a groundwater-fed rapid sand filter. Water Res. 129, 105-114. doi: 10.1016/j.watres.2017.10.073

Hedegaard, M. J., Prasse, C., and Albrechtsen, H. J. (2019). Microbial degradation pathways of the herbicide bentazone in filter sand used for drinking water treatment. Environ. Sci. 5, 521-532. doi: 10.1039/c8ew00790j

IWA (2014). International Statistics for Water Services. Available online at: http://www.iwa-network.org/wp-content/uploads/2016/06/InternationalStatistics-for-Water-Services-2014.pdf (accessed June 2, 2020).

Jagadevan, S., and Semrau, J. D. (2013). Priority pollutant degradation by the facultative methanotroph, methylocystis strain SB2. Appl. Microbiol. Biotechnol. 97, 5089-5096. doi: 10.1007/s00253-012-4310-y

Janniche, G. S., Lindberg, E., Mouvet, C., and Albrechtsen, H.-J. (2010). Mineralization of isoproturon, mecoprop and acetochlor in a deep unsaturated limestone and sandy aquifer. Chemosphere 81, 823-831. doi: 10.1016/j. chemosphere.2010.08.023

Kolpin, D. W., Barbash, J. E., and Gilliom, R. J. (2000). Pesticides in ground water of the United States, 1992-1996. Ground Water 38, 858-863. doi: 10.1111/j.17456584.2000.tb00684.x

Kotelnikova, S. (2002). Microbial production and oxidation of methane in deep subsurface. Earth Sci. Rev. 58, 367-395. doi: 10.1016/S0012-8252(01)00082-4

Kulongoski, J. T., and McMahon, P. B. (2019). Methane emissions from groundwater pumping in the USA. NPJ Clim. Atmos. Sci. 2:26. doi: 10.1038/ s41612-019-0068-6

Lee, C. O., Boe-Hansen, R., Musovic, S., Smets, B., Albrechtsen, H.-J., and Binning, P. (2014). Effects of dynamic operating conditions on nitrification in biological rapid sand filters for drinking water treatment. Water Res. 64, 226-236. doi: 10.1016/j.watres.2014.07.001

Lontoh, S., DiSpirito, A. A., Krema, C. L., Whittaker, M. R., Hooper, A. B., and Semrau, J. D. (2000). Differential inhibition in vivo of ammonia monooxygenase, soluble methane monooxygenase and membrane-associated methane monooxygenase by phenylacetylene. Environ. Microbiol. 2, 485-494. doi: 10.1046/j.1462-2920.2000.00130.x

Loos, R., Locoro, G., Comero, S., Contini, S., Schwesig, D., Werres, F., et al. (2010). Pan-European survey on the occurrence of selected polar organic persistent pollutants in ground water. Water Res. 44, 4115-4126. doi: 10.1016/j.watres. 2010.05.032

Luo, Y., Atashgahi, S., Rijnaarts, H. M., Comans, N. J., and Sutton, N. B. (2019). Influence of different redox conditions and dissolved organic matter on pesticide biodegradation in simulated groundwater systems. Sci. Total Environ. 677, 692-699. doi: 10.1016/j.scitotenv.2019.04.128

Lytle, D. A., Sorg, T. J., Muhlen, C., Wang, L., Rahrig, M., French, K., et al. (2007). Biological nitrification in a full-scale and pilot-scale iron removal drinking water treatment plant. J. Water Supply 56:125. doi: 10.2166/aqua.2007.092
Maksimavičius, E., and Roslev, P. (2020). Methane emission and methanotrophic activity in groundwater-fed drinking water treatment plants. Water Supply 20 , 819-827. doi: 10.2166/ws.2020.009

Mouchet, P. (1992). From conventional to biological removal of iron and manganese in France. J. Am. Water Works Assoc. 84, 158-167.

Palomo, A., Fowler, J., Gülay, A., Rasmussen, S., Sicheritz-Ponten, T., and Smets, B. F. (2016). Metagenomic analysis of rapid gravity sand filter microbial communities suggests novel physiology of Nitrospira spp. ISME J. 10, 25692581. doi: 10.1038 /ismej.2016.63

Papadopoulou, A., Hedegaard, M., Dechesne, A., Albrechtsen, H. J., Musovic, S., and Smets, B. F. (2019). Methanotrophic contribution to biodegradation of phenoxy acids in cultures enriched from a groundwater-fed rapid sand filter. Appl. Microbiol. Biotechnol. 103, 1007-1019. doi: 10.1007/s00253-0189501-8

Prior, S. D., and Dalton, H. (1985). Acetylene as a suicide substrate and active site probe for methane monooxygenase from Methylococcus capsulatus (Bath). FEMS Microbiol. Lett. 29, 105-109.

Schipper, P. N. M., Vissers, M. J. M., and van der Linden, A. M. A. (2008). Pesticides in groundwater and drinking water wells: overview of the situation in the Netherlands. Water Sci. Technol. 57, 1277-1286. doi: 10.2166/wst.2008.255

Semprini, L., Roberts, P. V., Hopkins, G. D., and McCarty, P. L. (1990). A field evaluation of in-situ biodegradation of chlorinated ethenes: part 2, results of biostimulation and biotransformation experiments. Groundwater 28, 715-727. doi: 10.1111/j.1745-6584.1990.tb01987.x

Semrau, J. D., Dispirito, A. A., and Yoon, S. (2010). Methanotrophs and copper. FEMS Microbiol. Rev. 34, 496-531. doi: 10.1111/j.1574-6976.2010.00212.x

Semrau, J. D., Jagadevan, S., Dispirito, A. A., Khalifa, A., Scanlan, J., Bergman, B. H., et al. (2013). Methanobactin and MmoD work in concert to act as the "copper-switch" in methanotrophs. Environ. Microbiol. 15, 3077-3086. doi: $10.1111 / 1462-2920.12150$

Sirajuddin, S., and Rosenzweig, A. C. (2015). Enzymatic oxidation of methane. Biochemistry 54, 2283-2294. doi: 10.1021/acs.biochem.5b00198

Sullivan, J. P., and Chase, H. A. (1996). 1,2,3-Trichlorobenzene transformation by Methylosinus trichosporium OB3b expressing soluble methane monooxygenase. Appl. Microbiol. Biotechnol. 45, 427-433.

Tekerlekopoulou, A. G., Pavlou, S., and Vayenas, D. V. (2013). Removal of ammonium, iron and manganese from potable water in biofiltration units: a review. J. Chem. Technol. Biotechnol. 88, 751-773. doi: 10.1002/jctb. 4031

Trotsenko, Y. A., and Murrell, J. C. (2008). Metabolic aspects of aerobic obligate methanotrophy. Adv. Appl. Microbiol. 63, 183-229. doi: 10.1016/ S0065-2164(07)00005-6

van der Hoek, J. P., Hofman, J. A. M. H., and Graveland, A. (1999). The use of biological activated carbon filtration for the removal of natural organic matter and organic micropollutants from water. Water Sci. Technol. 40, 257-264. doi: 10.1016/S0273-1223(99)00664-2

Vandermaesen, J., Horemans, B., Degryse, J., Boonen, J., Walravens, E., and Springael, D. (2019). The pesticide mineralization capacity in sand filter units of drinking water treatment plants (DWTP): consistency in time and relationship with intake water and sand filter characteristics. Chemosphere 228, 427-436. doi: 10.1016/j.chemosphere.2019.04.033

Xu, Y., Yuan, Z., and Ni, B. J. (2017). Impact of ammonium availability on atenolol biotransformation during nitrification. ACS Sustain. Chem. Eng. 5, 7137-7144. doi: 10.1021/acssuschemeng.7b01319

Zearley, T. L., and Summers, R. S. (2012). Removal of trace organic micropollutants by drinking water biological filters. Environ. Sci. Technol. 46, 9412-9419. doi: $10.1021 / \mathrm{es} 301428 \mathrm{e}$

Conflict of Interest: The authors declare that the research was conducted in the absence of any commercial or financial relationships that could be construed as a potential conflict of interest.

Copyright (c) 2020 Hedegaard, Schliemann-Haug, Milanovic, Lee, Boe-Hansen and Albrechtsen. This is an open-access article distributed under the terms of the Creative Commons Attribution License (CC BY). The use, distribution or reproduction in other forums is permitted, provided the original author(s) and the copyright owner(s) are credited and that the original publication in this journal is cited, in accordance with accepted academic practice. No use, distribution or reproduction is permitted which does not comply with these terms. 